Krystyna Mihułka

Uniwersytet Rzeszowski

kmihulka@gmail.com

\title{
SYLWETKA ABSOLWENTA FILOLOGII GERMAŃSKIEJ O SPECJALNOŚCI NAUCZYCIELSKIEJ A RZECZYWISTY STAN PRZYGOTOWANIA KANDYDATÓW DO ZAWODU NAUCZYCIELA
}

\section{Profiling the graduate of German Philology with a specialization in the teaching of German and the de facto state of students' preparation for work in the teaching profession}

The article presents and discusses the results of a questionnaire conducted among third-year undergraduate students and second-year graduate students of German Philology at the University of Rzeszów taking the specialization in the teaching of German. The aim of the questionnaire was to draw attention to and assess the current state of the students' preparation for work in the teaching profession. Analysis of the results reveals to what extent the programme of studies in the Department of German Philology, particularly within the teaching specialization, fulfils the students' expectations. In addition, the respondents' proposals concerning how the quality of teacher education in the Department of German Philology could be improved are presented and discussed by the author.

Keywords: teacher training, programme of studies, teaching specialization, methodology of teaching German

Słowa kluczowe: edukacja nauczycieli, program kształcenia, specjalność nauczycielska, metodyka nauczania języka niemieckiego 


\section{Wstęp}

Spadająca z roku na rok liczba studentów filologii germańskiej, wybierających podczas studiów specjalność nauczycielską, świadczy jednoznacznie o tym, iż zawód nauczyciela języka niemieckiego przestał się cieszyć tak dużą popularnością jak dawniej. Jest to spowodowane głównie tym, że zawodu tego nie można już uznać za dający pewne zatrudnienie, ponieważ rokrocznie zwalnianych jest wielu nauczycieli, dla których na skutek niżu demograficznego i związanego z nim łączenia klas brakuje wystarczającej liczby godzin dla zapewnienia etatu. Ponadto w znacznej większości szkół gimnazjalnych i ponadgimnazjalnych na Podkarpaciu - w zasadzie w całej Polsce - język niemiecki jest drugim językiem obcym ${ }^{1}$, po języku angielskim, co powoduje, że wielu uczniów nie widzi sensu uczenia się języka, który nie jest tak przydatny jak język angielski.

Na pierwszy rzut oka wydaje się, że trudno zmienić ten stan rzeczy, gdyż rzeczywiście nie mamy wpływu ani na demografię w naszym kraju, ani na sytuację na rynku pracy. Jednak możemy zastanowić się nad tym, czy przyczyna niewybierania przez studentów specjalności nauczycielskiej leży tylko po stronie wyżej wymienionych czynników, czy może wpływ na ich decyzję ma również program kształcenia na specjalności nauczycielskiej, który po prostu nie spełnia ich oczekiwań?

W celu uzyskania informacji, jak studenci filologii germańskiej Uniwersytetu Rzeszowskiego oceniają przebieg kształcenia na specjalności nauczycielskiej, przeprowadziłam ankietę wśród przyszłych adeptów zawodu nauczyciela języka niemieckiego, tj. studentów ostatniego roku studiów pierwszego i drugiego stopnia. Zebrane na jej podstawie wyniki dają możliwość podjęcia pewnych kroków naprawczych - głównie uwzględnienia i rozważenia sugestii ankietowanych - a w przyszłości wyjścia naprzeciw oczekiwaniom studentów i udoskonalenia obowiązujących programów kształcenia na kierunku filologia germańska, specjalność nauczycielska.

\section{Opis badania}

Opisywane badanie o charakterze poprzecznym - określane w literaturze przedmiotu także mianem diagnozy poprzecznej (por. Komorowska, 1982: 172-190) - przeprowadzono w maju 2014 roku wśród 47 studentów filologii germańskiej UR ostatniego roku studiów licencjackich (40 osób) ${ }^{2}$ i magisterskich uzupełniających (7

\footnotetext{
${ }^{1} \mathrm{~W}$ wielu szkołach ponadgimnazjalnych w województwie podkarpackim uczniowie mają możliwość wybrania jako drugiego języka obcego także języka hiszpańskiego.

${ }^{2}$ Należy dodać, iż ankietowani studenci stanowili ostatnią tak liczną grupę osób wybierających podczas studiów licencjackich specjalność nauczycielską. Na obecnym II
} 
Sylwetka absolwenta filologii germańskiej o specjalności nauczycielskiej...

osób) specjalności nauczycielskiej³. Badana populacja dobrana została w sposób celowy, a biorąc pod uwagę jej wielkość, zaliczana jest do prób „przejściowych” (Łobocki, 2009: 175). Jeśli zaś chodzi o liczbę badanych w poszczególnych grupach, to daje się zauważyć olbrzymią dysproporcję, będącą odzwierciedleniem liczby studentów wybierających specjalność nauczycielską na obydwu stopniach ${ }^{4}$.

W badaniu uczestniczyły 44 kobiety i 3 mężczyzn, co potwierdza fakt, że studia filologiczne były i nadal są studiami mocno sfeminizowanymi. Spośród badanych tylko dwie osoby miały styczność z nauczaniem innych - jedna osoba z gr. I prowadziła trzymiesięczny kurs dla początkujących i jedna osoba z gr. II pracowała od dziewięciu miesięcy na stanowisku nauczyciela języka niemieckiego.

\section{Ilościowa i jakościowa analiza zebranych danych}

Dane zebrane przy pomocy anonimowej ankiety, składającej się z metryczki oraz 15 pytań $^{5}$ o charakterze zamkniętym i otwartym ${ }^{6}$, poddano analizie ilościowej i jakościowej. Podczas ich prezentacji zachowany został podział na dwa zakresy tematyczne: holistyczna ocena przebiegu kształcenia na specjalności nauczycielskiej oraz ocena przedmiotu bezpośrednio przygotowującego do zawodu nauczyciela, tj. metodyki nauczania języka niemieckiego jako obcego ${ }^{7}$.

roku była już tylko jedna grupa nauczycielska, a deklaracje studentów I roku pozwolą na utworzenie także tylko jednej grupy z tą specjalnością.

${ }^{3}$ Grupy objęte badaniem nie były uczone przedmiotu metodyka nauczania języka niemieckiego jako obcego przez autorkę tego artykułu.

${ }^{4}$ I tak jak dane zebrane wśród studentów III roku studiów licencjackich dostarczają wiedzy aplikatywnej, na podstawie której można formułować dyrektywy metodyczne, tak wyniki uzyskane na podstawie wypowiedzi siedmiu osób z II roku studiów magisterskich takiej wiedzy już nie dostarczają, a wyniki procentowe zniekształcają raczej ogólny wynik. Celowo jednak podczas analizy ilościowej zachowuję również podział na dwie grupy (gr. I - studia licencjackie, gr. II - studia magisterskie uzupełniające), gdyż dają się zaobserwować pewne ciekawe tendencje występujące tylko w obrębie jednej z grup lub obydwu, tyle że z różnym natężeniem.

${ }^{5}$ Poniżej przedstawione i omówione zostały wypowiedzi ankietowanych tylko na te pytania, które bezpośrednio związane są z tematem i celem niniejszego artykułu.

${ }^{6} \mathrm{Na}$ większość pytań należało udzielić jednoznacznej odpowiedzi „tak” lub „nie”, a następnie uzasadnić ją. Mimo iż w poleceniu studenci poproszeni zostali o uzasadnienie swojego zdania, to i tak nie wszyscy to uczynili. Oprócz tego typu pytań ankieta zawierała pytania zamknięte, w których wystarczyło spośród podanych odpowiedzi zaznaczyć te, z którymi respondenci się identyfikowali. Ponadto znalazły się w niej pytania otwarte polegające najczęściej na wymienieniu kilku cech / trudności / zagadnień etc.

${ }^{7} \mathrm{~W}$ tym miejscu chcę wyjaśnić, dlaczego w niektórych fragmentach niniejszej publikacji pojawia się pojęcie metodyka, a w innych glottodydaktyka, aby Czytelnik nie pomyślał, 
Stwierdzenia i sugestie ankietowanych opatrzone zostały moim komentarzem. We wnioskach przedstawiono ogólne wyniki pochodzące z autoewaluacji, tzn. studenci sami ocenili swój stopień przygotowania do pracy na stanowisku nauczyciela języka niemieckiego, oraz określono najistotniejsze trudności w kształceniu studentów, a także podano propozycje zmian.

\subsection{Holistyczna ocena przebiegu kształcenia na kierunku filologia germańska - specjalność nauczycielska}

Pierwsze z pytań ankiety dostarczyło informacji pozwalających udzielić odpowiedzi na pytanie, czy przebieg kształcenia w ramach specjalności nauczycielskiej pokrywa się z oczekiwaniami badanych studentów, czy też nie. Okazało się, że tylko ok. $23 \%$ (gr. I-22,5\%, gr. II -28,6\%) ankietowanych było zadowolonych z procesu kształcenia, podkreślając automatycznie, że właśnie tak wyobrażali sobie studia o wspomnianej specjalności. Ponad $76 \%$ (gr. I - 77,5\%, gr. II $71,4 \%)$ respondentów było natomiast zdania, że dotychczas proponowany przebieg kształcenia na specjalności nauczycielskiej nie jest odpowiedni, a studia nie spełniły ich oczekiwań. Ankietowani studenci szczególnie skarżyli się na zbyt małą liczbę przedmiotów metodycznych o charakterze praktycznym, które umożliwiłyby im wczucie się w realne sytuacje szkolne (23,45\%), jak również na fakt, iż w obrębie tej specjalizacji oferowanych jest za mało przedmiotów stricte metodycznych, pozwalających na uzyskanie kompleksowego wykształcenia jako nauczyciel języka niemieckiego (19,1\%). Przyszli nauczyciele języka niemieckiego podzielili się m.in. następującymi przemyśleniami - „Na specjalizacji nauczycielskiej jest parę zbędnych przedmiotów, które można by zastąpić przedmiotami metodycznymi, przygotowującymi studentów do praktyki, a w przyszłości do pracy na stanowisku nauczyciela języka niemieckiego”; „Myślę, że na specjalizacji nauczycielskiej właśnie metodyka powinna być przedmiotem wiodącym, a inne przedmioty powinny być ograniczone do minimum."

Ostatnie stwierdzenie to nieco zmodyfikowana myśl Gruczy (1988: 60), który już ponad ćwierć wieku temu podkreślał, iż w obrębie studiów nauczycielskich

iż stosuję te dwa terminy zamiennie. Otóż w programie kształcenia, planach studiów, siatkach godzin widnieje przedmiot metodyka nauczania języka niemieckiego jako obcego i w skonstruowanej przeze mnie ankiecie zmuszona byłam użyć również tej nazwy. Jednak zakres programowy tego przedmiotu znacznie wykracza poza cele i założenia metodyki i bliżej mu do glottodydaktyki, która „z jednej strony to praktyczne nauczanie języków obcych, a drugiej zaś nauka zajmująca się badaniem zarówno nauczania, jak i przyswajania sobie (akwizycji) języków" (Grucza, 1979: 5). W związku z powyższym we wszystkich tych fragmentach artykułu, w których nie odnoszę się bezpośrednio do wypowiedzi ankietowanych, używam terminu glottodydaktyka. 
Sylwetka absolwenta filologii germańskiej o specjalności nauczycielskiej...

„miejsce dziedziny podstawowej i zarazem wiodącej należy się z natury rzeczy glottodydaktyce i tylko tej dziedzinie." Literaturoznawstwo i lingwistyka powinny się znaleźć także w programie studiów nauczycielskich, tyle że - zdaniem Gruczy - będą one jedynie pełniły funkcję dziedzin „pomocniczych czy uzupełniających", a nie kluczowych. Niestety od tamtej pory niewiele się zmieniło. W ramach studiów filologicznych obecny jest wprawdzie podział na specjalności, najczęściej specjalność translatorską i nauczycielską, jednakże zarówno liczba godzin przeznaczonych na moduł specjalizacyjny nauczycielski, jak i sam dobór przedmiotów wydają się tylko w sposób minimalny nawiązywać do postulatów Zabrockiego (1962) i Gruczy $(1988,1993)^{8}$.

Analiza planów studiów i programów kształcenia ${ }^{9}$, na podstawie których przebiegało kształcenie uczestniczących w badaniu studentów, pokazuje, iż liczba godzin przewidziana na profesjonalne przygotowanie studentów do zawodu nauczyciela języka niemieckiego (chodzi o blok przedmiotów specjalizacyjnych) wynosi na studiach pierwszego stopnia 300 godz. + 200 godz. praktyk, podczas gdy na przedmioty stricte językoznawcze przeznaczono również 300 godz., a na blok praktycznej nauki języka niemieckiego (PNJN) - 660 godz. Jeśli zaś chodzi o poszczególne przedmioty wchodzące w skład specjalności nauczycielskiej i ich godzinową realizację, to dają się zauważyć również pewne niedociągnięcia. Na psychologię i pedagogikę przypada każdorazowo 30 godz., na metodykę nauczania języka niemieckiego - 105 godz. (75 godz. ćwiczeń i 30 godz. wykładu), na dydaktykę języka niemieckiego jako drugiego języka obcego-30 godz., na technologię informacyjną w szkole - 30 godz., na emisję głosu -30 godz. oraz na metodykę nauczania języka drugiego (angielskiego) - 30 godz. ${ }^{10}$.

\footnotetext{
${ }^{8}$ Na początku lat 60. ubiegłego wieku Zabrocki (1962: 45) postulował, aby w obrębie studiów neofilologicznych utworzyć odrębną specjalizację, której celem byłoby przygotowywanie kandydatów do zawodu nauczyciela. Specjalizacja ta, nazwana specjalizacją dydaktyczną, miała powstać i działać obok specjalizacji już istniejących, tj. specjalizacji literaturo- i językoznawczych, które w jego opinii kształciły naukowców w zakresie nazwanej specjalności, a nie jednocześnie nauczycieli języków obcych. Zabrocki swoimi postulatami zwrócił uwagę na problem specjalistycznego kształcenia kandydatów do zawodu nauczyciela, podkreślając tym samym, iż sama znajomość danego języka obcego jest niewystarczającym warunkiem, aby móc tytułować się mianem nauczyciela języka obcego. Postulaty Zabrockiego rozwinięte zostały przez Gruczę (1988, 1993), który w swoich rozważaniach jest bardziej radykalny i stanowczy, jeśli chodzi o kwestię profesjonalnego kształcenia nauczycieli języków obcych.

${ }^{9}$ http://www.ur.edu.pl/wydzialy/filologiczny/instytut-filologii-germanskiej/dydaktyk a/plany-studiow, DW 7.07.2014 r.

${ }^{10}$ Studenci uczestniczący w badaniu byli ostatnią grupą uzyskującą ze względu na wybraną specjalność - filologia germańska z językiem angielskim, specjalizacja nauczycielska -
} 
Na drugim stopniu studiów, na blok przedmiotów kształcenia nauczycielskiego (psychologia: 30 godz., pedagogika: 30 godz. oraz metodyka nauczania języka niemieckiego: 90 godz.) przewidziano w sumie 150 godz. + 60 godz. praktyk. Dla porównania na PNJN przeznaczone zostało 195 godz. ${ }^{11}$

Z powyższego zestawienia wynika, iż kurs metodyki, podczas którego studenci nota bene w pierwszej kolejności przygotowywani są do praktyk pedagogicznych, a następnie do zawodu nauczyciela, obejmuje na studiach licencjackich zaledwie 105 godz., natomiast na studiach magisterskich uzupełniających - 90 godz. Liczba przewidzianych godzin pozwala, oczywiście, na dość ogólnikową realizację podstawowych, obowiązkowych treści. Postulaty ankietowanych studentów dotyczące zwiększenia liczby godzin przedmiotów metodycznych bezpośrednio przygotowujących do zawodu nauczyciela kosztem innych zajęć, wydają się jak najbardziej uzasadnione. Ta dość niska liczba godzin wynika najczęściej z faktu, iż podczas opracowywania siatek godzin uwzględnia się minimalną liczbę godzin kształcenia metodycznego zaproponowaną w ministerialnym dokumencie, tj. Standardach kształcenia nauczycieli (języków obcych) ${ }^{12}$, na co już kilka lat temu zwracała uwagę Myczko (2009: 163).

Druga, sugerowana przez prawie $15 \%$ ankietowanych, propozycja zmian dotyczyła zwiększenia liczby godzin w obrębie bloku PNJN, mimo iż na ten blok przewidziana jest - w porównaniu z innymi treściami kształcenia - największa liczba godzin. Ankietowani zaznaczali, iż myśleli, że podczas studiów „będzie położony większy nacisk na kształcenie umiejętności językowych - konwersacja, słuchanie, słownictwo, gramatyka." Przychylne potraktowanie sugestii studentów w kwestii zwiększenia liczby godzin przewidzianych na praktyczną naukę języka stawia pod znakiem zapytania idee studiów neofilologicznych, które stałyby się wówczas intensywnym kursem językowym, jedynie z pewnymi elementami literaturoznawstwa, kulturoznawstwa, językoznawstwa i glottodydaktyki ${ }^{13}$. Już pod

uprawnienia do nauczania również języka angielskiego. Stąd w bloku przedmiotów specjalizacyjnych znalazła się metodyka nauczania języka drugiego, tj. angielskiego.

11 Trzeba zaznaczyć, iż kształcenie studentów na specjalności nauczycielskiej rozpoczynających studia w roku akademickim 2012/2013 przebiega w oparciu o inną, zmodyfikowaną siatkę godzin. Niestety, wprowadzone zmiany nie wypadają na korzyść przedmiotów przygotowujących do zawodu nauczyciela. W siatce tej na blok przedmiotów specjalizacyjnych przypada 390 godz. - z tego na metodykę nauczania języka niemieckiego tylko 120 godz. (90 godz. ćwiczeń i 30 godz. wykładu) oraz 150 godz. praktyk, podczas gdy na przedmioty stricte językoznawcze przeznaczono 480 godz., a na blok PNJN - 840 godz.

12 Szczegółową analizę obowiązujących Standardów kształcenia nauczycieli języków obcych przedstawiła Krzysiak (2013).

${ }^{13}$ Oczekiwania studentów są właśnie takie, tzn. oni przede wszystkim chcą nauczyć się języka, a wiedza z zakresu językoznawstwa, literaturoznawstwa, kulturoznawstwa czy 
Sylwetka absolwenta filologii germańskiej o specjalności nauczycielskiej...

koniec lat 80. XX w. Grucza $(1988: 54,59)$ określał program kształcenia neofilologicznego mianem „programu całkiem "uszkolnionego»” (pozbawionego jakiegokolwiek kształcenia naukowego), studiowanie mianem „dalszego uczenia się", zaś studia neofilologiczne mianem "ogólniaków neofilologicznych" - głównie za sprawą dużej liczby godzin poświęconych na praktyczną naukę języka obcego.

Problem związany z dość dużą liczbą godzin przeznaczonych na praktyczną naukę języka obcego podczas studiów filologicznych należy rozpatrywać z dwóch perspektyw. Oczywiście, z jednej strony taki sposób postępowania powoduje, że studia filologiczne przestają nimi być, co zaakcentowane zostało powyżej. $Z$ drugiej jednak strony poziom językowy studentów podejmujących studia językowe, przynajmniej biorąc pod uwagę filologię germańską w UR, jest z roku na rok coraz niższy, a niektórzy studenci są świadomi swoich braków w zakresie szeroko rozumianej kompetencji językowej oraz zdają sobie sprawę z oczekiwań wykładowców, którzy - zdaniem jednej z osób - „wychodzą z założenia, że studenci już znają język." Ankietowani wskazywali ponadto na swoje braki w zakresie znajomości języka niemieckiego specjalistycznego, pozwalającego na rozumienie treści przekazywanych w ramach poszczególnych przedmiotów fachowych, a nie praktycznych. I tak ponad $19 \%$ respondentów (chodzi o członków gr. I) chciałoby, aby skomplikowany metajęzyk glottodydaktyki zastąpić językiem bardziej przystępnym oraz aby pewne zagadnienia omawiać także w języku polskim („żeby chociaż część zajęć z metodyki odbywała się w języku polskim" $)^{14}$, co tylko potwierdza stosunkowo niski poziom

glottodydaktyki to już kwestie drugorzędne. Takie preferencje dają się zaobserwować wśród studentów filologii obcych w ogóle, nie tylko filologii germańskiej, o czym świadczą wyniki badania przeprowadzonego w 2007 r. wśród studentów filologii germańskiej i angielskiej. Okazało się, że dla niemal wszystkich ankietowanych opanowanie języka obcego na poziomie umożliwiającym komunikację z jego rodzimymi użytkownikami jest najważniejszym celem studiów filologicznych oraz czynnikiem najbardziej motywującym ich do studiowania na wybranym kierunku (patrz Mihułka, 2008: 46).

${ }^{14}$ Postulat zaproponowany przez studentów, dotyczący przekazywania na metodyce złożonych treści w języku polskim a nie niemieckim, jest po części słuszny. Podstawowym celem tych zajęć jest bowiem rozwijanie kompetencji dydaktycznej, a kształtowaniu kompetencji językowej poświęcone są inne zajęcia (PNJN). Należy jednak zachować odpowiednie proporcje w używaniu na metodyce języka ojczystego studentów i języka obcego (w tym wypadku niemieckiego). Nadużywanie języka ojczystego, czy prowadzenie zajęć tylko w tym języku, może doprowadzić do tego, że przyszli nauczyciele języka niemieckiego nie będą znać podstawowej niemieckojęzycznej terminologii z zakresu nauczania i uczenia się języka obcego. Korzystanie z niemieckojęzycznej literatury przedmiotu będzie zatem mocno ograniczone. 
językowy niektórych studentów (w większości tegorocznych - 2013/2014 absolwentów) filologii germańskiej pierwszego stopnia.

\subsection{Metodyka nauczania języka niemieckiego jako obcego - godziny, treści, wykładowca}

Kolejne pytania postawione w ankiecie dotyczyły przedmiotu metodyka nauczania języka niemieckiego. Skoncentrowano się głównie na tym, czy liczba godzin i treści oferowane w ramach metodyki są - zdaniem studentów - odpowiednio dobrane. Ponadto odniesiono się także do oczekiwań przyszłych nauczycieli języka niemieckiego względem osób prowadzących zajęcia z tego przedmiotu.

Ok. $60 \%$ ankietowanych (gr. I - 62,5\%, gr. II - 42,9\%) było zdania, że liczba godzin przeznaczona w programie studiów na metodykę nauczania języka niemieckiego jako obcego jest satysfakcjonująca. Wśród osób, które zdecydowały się uzasadnić swoje zdanie, przeważało stwierdzenie, iż podczas zajęć można omówić cały przewidziany materiał. Dla $40 \%$ respondentów (gr. I $37,5 \%$, gr. II - 57,1\%) liczba godzin metodyki nauczania języka niemieckiego jest zbyt mała i powinna zostać zwiększona, gdyż „podczas jednych tygodniowo zajęć z metodyki ciężko przygotować studentów do zawodu nauczyciela języka niemieckiego, przekazać im odpowiednią wiedzę" (12,8\%). Ok. $15 \%$ studentów sugerowało jednocześnie wprowadzenie podziału zajęć z metodyki na zajęcia teoretyczne i praktyczne - bezpośrednio przygotowujące do podjęcia pracy jako nauczyciel języka niemieckiego. Spośród osób niezadowolonych z liczby godzin metodyki tylko dwie były zdania, że jest ich za dużo i że są one wypełniane w szczególności treściami teoretycznymi.

W kolejnym pytaniu ankiety przyszli nauczyciele języka niemieckiego zostali poproszeni o zaznaczenie, którym zagadnieniom z zakresu metodyki nauczania języka niemieckiego jako obcego należałoby poświęcić więcej uwagi podczas zajęć, a którym - mniej. Pytanie to skonstruowano w oparciu o skalę Likerta ${ }^{15}$. Z lewej strony tabeli wyszczególnione zostały zagadnienia ${ }^{16}$, a respondenci zostali

\footnotetext{
${ }^{15}$ Patrz Oppenheim (2004: 226-227), Wilczyńska i Michońska-Stadnik (2010: 125).

16 Rozwijanie sprawności językowych, nauczanie gramatyki, nauczanie słownictwa, doskonalenie wymowy, poprawa błędów, ocena / ewaluacja wyników, rozwijanie autonomii uczniów, rozwijanie motywacji uczniów do nauki języka obcego, nauczanie interkulturowe, zastosowanie narzędzi technologii informacyjno-komunikacyjnej na lekcji języka obcego, planowanie i organizacja lekcji języka obcego (przygotowywanie konspektów, sporządzanie arkuszy hospitacyjnych, planów wynikowych, prowadzenie próbnych lekcji), zastosowanie gier i zabaw językowych na lekcji języka obcego, formy pracy z uczniami zdolnymi językowo, formy pracy z uczniami o różnym stopniu niepełnosprawności, inne.
} 
Sylwetka absolwenta filologii germańskiej o specjalności nauczycielskiej...

poproszeni o wyrażenie swojego stosunku do każdej z wymienionych kwestii w kategoriach „zdecydowanie tak”, „raczej tak”, „, nie wiem”, „raczej nie”, „zdecydowanie nie".

Ankietowani byli niemal jednomyślni $(93,6 \%)^{17}$ w kwestii tego, że na metodyce należy poświęcić najwięcej uwagi sposobom rozwijania czterech podstawowych sprawności językowych u uczniów. Na drugim miejscu uplasowało się rozwijanie motywacji uczniów do nauki języka obcego, na które wskazało prawie $90 \%{ }^{18}$ badanych. Zdaniem $87 \%{ }^{19}$ ankietowanych zagadnienia dotyczące poprawy błędów powinny być również szczegółowo omawiane w ramach metodyki nauczania języka niemieckiego jako obcego.

$\mathrm{Na}$ czwartym miejscu znalazły się ex aequo nauczanie słownictwa i formy pracy z uczniami o różnym stopniu niepełnosprawności, które zaznaczone zostały jako zagadnienia istotne przez prawie $83 \%$ respondentów. Ok. $80 \%$ ankietowanych było z kolei zdania, że w ramach metodyki więcej uwagi należy się następującym zagadnieniom: nauczanie gramatyki, doskonalenie wymowy, zastosowanie gier i zabaw językowych na lekcji języka obcego. Na szóstym miejscu znalazły się tematy związanie z zastosowaniem narzędzi technologii informacyjno-komunikacyjnej, na które wskazało ponad $72 \%$ badanych. Prawie $72 \%$ respondentów wyraziło przekonanie, że więcej miejsca na metodyce należałoby poświęcić zaprezentowaniu i omówieniu form pracy z uczniami zdolnymi językowo ${ }^{20}$. Na kolejnych miejscach uplasowały się takie zagadnienia, jak: sposoby oceniania / ewaluacji wyników (70,1\%) oraz rozwijanie autonomii uczniów (68,1\%). Przedostatnią lokatę zajęły treści związane z planowaniem i organizacją lekcji języka obcego - na ważność tych treści podczas zajęć z metodyki wskazało prawie $60 \%$ badanych. Ostatnie miejsce wśród zagadnień, którym w ramach metodyki należałoby poświęcić więcej uwagi, zajęły treści dotyczące nauczania interkulturowego, które jako istotne zaznaczyło tylko 57,5\% respondentów ${ }^{21}$.

\footnotetext{
17 59,6\% ankietowanych zaznaczyło „zdecydowanie tak”, a 34\% - „raczej tak”.

18 55,3\% ankietowanych zaznaczyło "zdecydowanie tak”, a 34\% - „raczej tak”.

19 31,5\% badanych zaznaczyło „zdecydowanie tak”, 55,3\% - „raczej tak”.

${ }^{20} \mathrm{Na}$ uwagę zasługuje niewątpliwie fakt, że $17 \%$ ankietowanych uznało, że w ramach zajęć z metodyki nie należy poświęcać uwagi omawianiu form pracy z uczniami wykazującymi ponadprzeciętne zdolności językowe. Ankietowani ci wychodzą najprawdopodobniej z założenia, że praca z uczniami (ponadprzeciętnie) zdolnymi językowo nie wymaga odpowiedniego przygotowania ze strony nauczycieli i w zasadzie niczym się nie różni od pracy z uczniami średnio lub mało uzdolnionymi językowo. Szerzej na temat form pracy z uczniami zdolnymi językowo w: Sobańska-Jędrych (2011).

${ }^{21} 19 \%$ badanych wyraziło zaś przekonanie, że tematów dotyczących nauczania interkulturowego w ogóle nie powinno się poruszać na zajęciach, a ponad $23 \%$ nie miało
} 
Zadaniem respondentów było również nazwanie tych treści nauczania, które w ich opinii nie są przydatne w zawodzie nauczyciela. Prawie $45 \%$ ankietowanych wymieniło $w$ tym pytaniu metody nauczania języka obcego - „to zupełnie bezsensowne uczyć się o jakiś przestarzałych metodach nauczania”; „,po co uczyć się historycznego podziału metod, lepiej poznać dokładnie metodę obecnie obowiązującą." Trudno w jednoznaczny sposób wyjaśnić przekonanie niemal połowy ankietowanych studentów o tym, iż charakteryzowanie wcześniej obowiązujących metod nauczania języka obcego w ramach metodyki jest „bezsensowne”. Być może wynika ono z faktu, iż studenci dość pragmatycznie podchodzą do nauki języka oraz bezpośredniego wykorzystania treści przyswojonych w procesie kształcenia w praktyce szkolnej. Może i omawianie „przestarzałych" metod nauczania wydaje się studentom nudne, jednak jest ono konieczne, aby można było w sposób właściwy usytuować obecnie obowiązującą metodę i ocenić ją, porównując z wcześniejszymi metodologiami.

W opinii ok. $10 \%$ studentów na zajęciach z metodyki powinno się zrezygnować z pisania konspektów - „jest zbyt duża ilość różnych modeli konspektów”; „nikt tego nie lubi - kiedy myślimy, że opanowaliśmy tę sprawność, to okazuje się, że jesteśmy w błędzie: co wykładowca, to inny model”; „pisanie nierealnych konspektów, których i tak nie da się zrealizować na lekcji ze względu na brak czasu, jest zupełnie bez sensu." Postawa ankietowanych, głównie gr. II, wynika prawdopodobnie z faktu, iż podczas studiów pierwszego stopnia opracowywanie konspektów przebiegało nieco w inny sposób (za sprawą prowadzącego) niż na studiach magisterskich. Mimo przekonania studentów o tym, że „pisanie konspektów” w ramach metodyki jest „bezsensowne", to trudno jest mi sobie wyobrazić, aby przyszli nauczyciele języka niemieckiego nie ćwiczyli tej umiejętności w ogóle.

Przebieg zajęć z metodyki nauczania języka niemieckiego - zresztą jak każdych innych - uzależniony jest nie tylko od tematów, które podczas nich mają zostać zrealizowane, lecz także od sposobu ich realizacji. Kluczową rolę w tym zakresie odgrywa wykładowca. W związku z powyższym warto przyjrzeć się oczekiwaniom ankietowanych studentów wobec wykładowców prowadzących

zdania w tej kwestii. Brak zainteresowania tymi zagadnieniami wśród studentów wynika najprawdopodobniej z braku wiedzy na temat wagi interkulturowości w procesie nauczania i uczenia się języka obcego. Na studiach licencjackich nie ma nawet przedmiotu komunikacja interkulturowa, który w jakimś stopniu wprowadziłby studentów $w$ to zagadnienie. Jedyne informacje na ten temat mogą uzyskać studenci na metodyce, najczęściej podczas omawiania podejścia interkulturowego, a biorąc pod uwagę liczbę godzin przewidzianych na ten przedmiot, można się domyślić, że są to informacje dość powierzchowne. 
Sylwetka absolwenta filologii germańskiej o specjalności nauczycielskiej...

zajęcia metodyka nauczania języka niemieckiego jako obcego, gdyż ich przynajmniej częściowe uwzględnienie może podnieść efektywność kształcenia w ramach tego przedmiotu.

Ponad połowa ankietowanych chciałaby, aby osoby prowadzące zajęcia poświęcały więcej czasu nie teorii, jak to ma zazwyczaj miejsce, lecz praktyce nauczania języka obcego oraz pokazywały, w jaki sposób teorię można przełożyć na praktykę na podstawie konkretnych przykładów (21,3\%). Studenci oczekują od wykładowcy „niewykładania żmudnej teorii, lecz wprowadzenia większej ilości ćwiczeń praktycznych z udziałem studentów”; „mniej teorii, która nie przydaje się aż tak bardzo. Praktyka jest najważniejsza, ćwiczenia praktyczne, co mogłam zauważyć na praktykach w szkole." Przyszli nauczyciele chcieliby ponadto, aby wykładowca dawał studentom rady i wskazówki, jak zwiększyć efektywność i skuteczność nauczania języka obcego $(19,1 \%)$, oraz przedstawił im możliwe sposoby radzenia sobie z problemami różnej natury - mogącymi się pojawić, zarówno podczas praktyk, jak i w pracy zawodowej $(6,4 \%)$. Studenci życzyliby sobie także, aby na zajęciach z metodyki wykładowca pokazał im, jak się pracuje z dziennikiem lekcyjnym (12,7\%) oraz wyjaśnit, przynosząc gotowe wzory, w jaki sposób należy opracowywać konspekty lekcji $(6,4 \%)$.

Powyższe sugestie ankietowanych studentów dotyczą wprowadzenia szeregu zmian w dotychczasowym procesie kształcenia nauczycieli języka niemieckiego, spośród których najważniejsze w ich opinii jest odejście od teorii na rzecz praktyki. Jednakże koncentrowanie się wykładowców w dużej mierze na teorii jest w moim przekonaniu niekoniecznie wynikiem ich złej woli, a raczej trudności, z którymi sami muszą się zmierzyć. Chodzi mi głównie o małą liczbę godzin przewidzianych na metodykę, podczas których zrealizowanie materiału obowiązkowego w stopniu podstawowym jest nierealne. Wykładowca, wprowadzając „zajęcia stricte praktyczne”, podczas których studenci sami prowadzą lekcje, hospitują lekcje koleżanek i kolegów, opracowują konspekty pod okiem wykładowcy, dydaktyzują teksty autentyczne etc., musi liczyć się z tym, że pewne zakresy tematyczne będą musiały zostać jedynie zasygnalizowane, a nie omówione dogłębnie. Ponadto trzeba mieć świadomość tego, że aby można było przekładać teorię na praktykę, najpierw należy poznać i uporządkować tę pierwszą. Pfeiffer (2001: 212) podkreślał wielokrotnie, iż praktyczne rozwiązania winny być zawsze osadzone w kontekście teoretycznym, dodając przy tym, że „nic nie jest bardziej praktyczne jak dobra teoria.”

Studenci oczekują ponadto od wykładowców większego zaangażowania, kreatywności i „mniej monotonii i przewidywalności” (17\%), jak również motywowania ich do podjęcia w przyszłości pracy jako nauczyciel języka niemieckiego $(10,6 \%)$. 


\section{Wnioski}

Wyniki zebrane w badaniu ankietowym pozwalają na nazwanie najistotniejszych trudności w kształceniu przyszłych adeptów zawodu nauczyciela języka obcego, w tym wypadku niemieckiego. Przezwyciężenie ich zwiększyłoby efektywność kształcenia oraz wzmocniłoby motywację studentów do nauki przedmiotów bezpośrednio przygotowujących do pracy na stanowisku nauczyciela języka niemieckiego. Do najczęściej wymienianych i zarazem najważniejszych trudności należą:

- Niski poziom językowy kandydatów rozpoczynających studia na kierunku filologia germańska - specjalność nauczycielska.

a) W celu wyrównania różnic w poziomie kompetencji językowej studentów wprowadzono dla osób rozpoczynających studia od poziomu A1 intensywny kurs języka niemieckiego (480 godz.), pozwalający na osiągnięcie na koniec pierwszego roku poziomu B1, co niestety nie zawsze staje się faktem.

b) Przeznaczenie tak dużej liczby godzin na praktyczną naukę języka wiąże się ze zmniejszeniem liczby godzin przedmiotów specjalistycznych.

c) Ponadto następstwem braków w kompetencji językowej studentów jest dwujęzyczne (w języku niemieckim i polskim) omawianie zagadnień na wielu przedmiotach specjalistycznych. Trudno zatem zrealizować zaplanowane treści w pełni.

d) Stosunkowo niski poziom językowy studentów filologii germańskiej jest w dużej mierze następstwem niewłaściwego kształcenia na szczeblach niższych - wspomnę tylko o nierzadko "fikcyjnej" kontynuacji drugiego języka obcego (niemieckiego) w poszczególnych typach szkół (por. Mihułka, 2012: 161-163; 341).

- Mała liczba godzin przewidziana w programach nauczania na przedmioty bezpośrednio przygotowujące do zawodu nauczyciela języka niemieckiego. Zwiększenie liczby godzin zajęć, podczas których główny nacisk położony jest na rozwój kompetencji dydaktycznej studentów i ogólne przygotowanie ich do pracy na etacie nauczyciela języka niemieckiego w przyszłości, pozwoliłoby na bardziej szczegółowe, a nie tylko ogólnikowe omawianie treści ujętych w karcie przedmiotu. Zrealizowanie tego postulatu wydaje się jednak dość trudne, przede wszystkim z dwóch przyczyn. Po pierwsze dlatego, że nie jestem osobą decyzyjną w kwestii opracowywania programów kształcenia i planów studiów, zgłaszane przeze mnie propozycje, spotykają się z odmową. Po drugie liczba godzin wielu przedmiotów specjalistycznych, nie tylko metodyki, jest skracana na rzecz praktycznej nauki języka. 
Sylwetka absolwenta filologii germańskiej o specjalności nauczycielskiej...

- Koncentrowanie się na metodyce głównie na treściach teoretycznych, mniej na ich praktycznym zastosowaniu.

Taki stan rzeczy wiąże się bezpośrednio z powyższym punktem. Mała liczba godzin powoduje, że trudno zrealizować materiał podstawowy określony w sylabusie, a co dopiero wprowadzić w życie postulat uczestniczących w badaniu studentów dotyczący podziału zajęć z metodyki na zajęcia praktyczne i teoretyczne.

Myślę jednak, że warto wyjść naprzeciw oczekiwaniom studentów i przekazywać im podczas zajęć więcej praktycznych rozwiązań, nawiązując oczywiście do treści teoretycznych, które musieliby w znacznej większości opracowywać w domu sami.

- Małe zaangażowanie wykładowców w przygotowywanie i prowadzenie bardziej różnorodnych zajęć.

Przezwyciężenie tej trudności wydaje się najłatwiejsze do wykonania, gdyż uzależnione jest tylko od wykładowców, a nie od osób trzecich. Propozycja studentów odnosząca się do prowadzenia bardziej urozmaiconych zajęć $z$ metodyki może wejść $w$ życie w zasadzie natychmiast. Wystarczy, aby wykładowcy stali się bardziej kreatywni i zmienili formułę swoich zajęć, wykorzystując np. narzędzia technologii informacyjno-komunikacyjnej, prezentując i omawiając wyniki badań ukazujące autentyczne problemy, z którymi muszą się zmierzyć nauczyciele języków obcych (w Polsce i w innych krajach), zachęcając studentów do pracy twórczej, tj. pozwalając im wykonywać pomoce dydaktyczne (pacynki, plansze do gier, plakaty etc.).

Mimo wyżej opisanych usterek obecnych w procesie kształcenia przyszłych nauczycieli języka niemieckiego w UR 2/3 studentów uczestniczących w badaniu uważa się za odpowiednio przygotowanych do podjęcia pracy jako nauczyciel języka niemieckiego. Odmiennego zdania jest $1 / 3$ ankietowanych, która mimo prawie skończonych studiów nie czuje się odpowiednio wykształcona, aby móc wykonywać ten zawód. W tym miejscu należy wyraźnie podkreślić, iż studenci kończący studia filologiczne o specjalności nauczycielskiej są wyposażeni jedynie w tzw. kompetencję wstępnq ${ }^{22}$, na bazie której rozwija się kompetencja profesjonalna. Zaczyna się ona kształtować od momentu podjęcia pracy dydaktycznej i podlega przemianom w ciągu całej kariery nauczyciela. Jest ona określana jako „ruchomy cel”, w kierunku którego profesjonalni nauczyciele podążają przez całe swoje zawodowe życie (por. Wysocka, 2003: 11).

\footnotetext{
${ }^{22}$ Kompetencja wstępna to „formalne, np. poświadczone dyplomem, stwierdzenie, że ktoś spełnia stawiane mu wymagania i jest już uprawniony do wykonywania zawodu nauczyciela" (Wallace, 1995, cyt. za Wysocką, 2003: 11).
} 
W tym miejscu należy podkreślić, że wszyscy studenci uczestniczący w opisywanym badaniu są zdania, że kształcenie nauczycieli języka obcego nie kończy się wraz z zakończeniem studiów filologicznych. Są więc świadomi tego, iż nabyta przez nich kompetencja wstępna to jedynie punkt wyjścia a nie punkt finalny w zawodzie nauczyciela języka niemieckiego pragnącego uchodzić za profesjonalistę. Pozostaje zatem żywić nadzieję, że to duże zaangażowanie studentów, prawie absolwentów filologii germańskiej, jak i deklarowana przez nich chęć dalszego doskonalenia warsztatu pracy nauczyciela pozwoli na zniwelowanie niedociągnięć i wypełnienie luk w niedoskonałych programach kształcenia nauczycieli oraz w ich nie do końca właściwej realizacji.

\section{BIBLIOGRAFIA}

Grucza, F. 1979. „Rozwój i stan glottodydaktyki polskiej w latach 1945-1975” (w) Polska myśl glottodydaktycza 1945-1975. Wybór artykułów z zakresu glottodydaktyki ogólnej (red. F. Grucza). Warszawa: Państwowe Wydawnictwo Naukowe: 5-16.

Grucza, F. 1988. „O filologii, neofilologii i kształceniu nauczycieli języków obcych” (w) Problemy ksztatcenia nauczycieli języków obcych. Materiały z XI Ogólnopolskiego Sympozjum zorganizowanego przez Instytut Lingwistyki Stosowanej UW w Jaszowcu, 7-10 listopada 1985 (red. F. Grucza). Warszawa: Wydawnictwa Uniwersytetu Warszawskiego: 176-117.

Grucza, F. 1993. „Ansätze zu einer Theorie der Ausbildung von Fremdsprachenlehrern" (w) Beiträge zur wissenschaftlichen Fundierung der Ausbildung von Fremdsprachenlehrern (red. F. Grucza, H.-J. Krumm i B. Grucza). Warszawa: Wydawnictwa Uniwersytetu Warszawskiego: 7-96.

Komorowska, H. 1982. Metody badań empirycznych w glottodydaktyce. Warszawa: PWN. Krzysiak, L. 2013. „Neue Standards für die Lehrebildung in Polen: Merkmale, Funktionen und mögliche Folgen" (w) Blickpunkte der Germanistik. Literatur- und Kulturwissenschaft, Linguistik und Fremdsprachendidaktik. Tom 1 (red. L. Krzysiak). Frankfurt am Main: Peter Lang Verlag: 155-164.

Łobocki, M. 2009. Wprowadzenie do metodologii badań pedagogicznych. Kraków: Oficyna Wydawnicza Impuls.

Mihułka, K. 2008, „Wpływ treści kulturo- i krajoznawczych na wzmocnienie motywacji u studentów filologii obcych" (w) Nowe spojrzenia na motywację w dydaktyce języków obcych. Tom 2. (red. A. Michońska-Stadnik i Z. Wąsik). Wrocław: Wyd. Wyższej Szkoły Filologicznej: 43-52.

Mihułka, K. 2012. Rozwój kompetencji interkulturowej w warunkach szkolnych - mity a szkolna rzeczywistość. Na przykładzie języka niemieckiego jako obcego. Rzeszów: Wydawnictwo Uniwersytetu Rzeszowskiego.

Myczko, K. 2009. „Kształcenie nauczycieli języków obcych i praktyka zawodowa” (w) Nauczyciel języków obcych dziś i jutro (red. M. Pawlak, A. Mystkowska-Wiertelak 
Sylwetka absolwenta filologii germańskiej o specjalności nauczycielskiej...

i A. Pietrzykowska). Kalisz-Poznań: Wydział Pedagogiczno-Artystyczny UAM w Kaliszu/ UAM w Poznaniu: 157-165.

Oppenheim, A.-N. 2004. Kwestionariusze, wywiady, pomiary postaw. Poznań: Wyd. Zysk i S-ka.

Pfeiffer, W. 2001. Nauka języków obcych. Od praktyki do praktyki. Poznań: Wagros.

Sobańska-Jędrych, J. 2011. „Rozwijanie zdolności do nauki języków obcych w szkole raport z badań" (w) Nauczanie języka obcego a specyficzne potrzeby uczq̨cych się (red. J. Knieja i S. Piotrowski). Lublin: Towarzystwo Naukowe KUL/ Katolicki Uniwersytet Lubelski Jana Pawła II: 51-62.

Wilczyńska, W., Michońska-Stadnik, A. 2010. Metodologia badań w glottodydaktyce. Wprowadzenie. Kraków: wyd. AVALON.

Wysocka, M. 2003. Profesjonalizm w nauczaniu języków obcych. Katowice: Wydawnictwo Uniwersytetu Śląskiego.

Zabrocki, L. 1962. „Reorganizacja studiów neofilologicznych”. Życie Szkoły Wyższej X(5): 43-51. 